\title{
SKRIFTUURLIKE FUNDERING EN SKRIFGEBONDENHEID VAN DIE PREDIKING
}

\author{
Dr. D. J. BOOYSEN
}

\section{Algemene Opmerking}

Augustinus, en in aansluiting by sy uitspraak, die Nederlandse Geloofsbelydenis (Art. XXIX), het verklaar dat die ware kerk eksisteer rondom die evangelium pure docetur et recte administrantur sacramenta. Dit is derhalwe te begrype dat die prediking in die kerk voortdurend onder die vergrootglas geplaas moet word vir deeglike ontleding. Die kerk het 'n verkondigingstaak in die wêreld. Hierdie verkondiging neem verskillende gestaltes aan waarvan die erediens van die gemeente sekerlik die belangrikste is. Danksy die toedoen van die Reformatore het die prediking ook in die erediens weer sentrale plek ingeneem en is dit vandag nog, ongeag die kritiek wat deur talle uitgespreek is, een van die hoofmomente in die erediens.

'n Ander feitelike situasie wat ek terloops hier wil noem is die swak kerkbesoek in ons kerk oor die algemeen. Wanneer die situasie ontstaan dat die lidmate van die kerk hulleself onttrek aan die geleentheid waartydens hulle geloof versterk word ${ }^{1}$ dan moet die kerk ook vra na sy eie aandeel aan die situasie en met name na die prediking in die kerk.

Touw $^{2}$ het gewys op die verset teen die prediking. Jonker ${ }^{3}$ en Thielicke ${ }^{4}$ het ook gewys op die besware wat ten regte of ten onregte ingebring word teen die prediking. Touw vind oplossing daarin dat die kerk nie minder moet preek nie maar dat daar sprake moet wees van ,andere prediking". Hierdie vernuwing waarvoor hy pleit moet noodwendig beteken dat opnuut weer besin moet word oor die prediking.

\section{Wat word bedoel met prediking}

Barth ${ }^{5}$ het 'n geslaagde poging aangewend om die prediking te formuleer: „Die Predigt ist der der Kirche befohlene Versuch,

1. Vraag en antwoord 49, 50 van die Kort Begrip.

2. H. C. Touw, Verontrustende Prediking, G. F. Callenbach N.V., Nijkerk, s.i. hl 7

3. H. Jonker, Actuele Prediking, G. F. Callenbach N.V., Nijkerk s.j., bl. 11. 12

4. Helmut Thielicke, The Trouble with the Church, translated by John. W. Doberstein, Harper \& Row, New York, 1965, bl. 5 v.v.

5. Karl Barth, Homiletik, EVZ - Verlag, Zürich 1966, bl. 30. 
dem Worte Gottes selbst durch einen dazu Berufenen so zu dienen, dass ein biblischer Text Menschen der Gegenwart als gerade sie angehend in freier Rede erklārt wird als Ankündigung dessen, was sie von Gott selbst zu hören haben."

Hiervolgens is die prediking amptelike opdrag aan die kerk wat dit langs die bepaalde weg ten uitvoer bring. De Wet $^{6}$ het 'n ander nuanse daaraan verleen wanneer hy verklaar dat die prediking die liturgiese verbesondering van die leer van die kerk is. Inhoudelik ontvang die prediking sy gids en sy grense uit die leer van die kerk en as gestalte van die verkondiging het dit dieselfde inhoud, nl. die „een woord van God". By Barth lê die aksent by die inhoudelike terwyl De Wet ook die formele aspek ingesien het, ofskoon ons nie nou aandag aan hierdie aspek sal gee nie.

In 'n poging om die prediking nader te omskrywe moet terug gegaan word na die toepaslike vakterminologie. Die oudste naam vir die prediking is homilie en die vakterm homilëtike is 'n samestelling wat dui op opeenhoping, saambring, verenig of ook gesellig verkeer. Later ontwikkel hieruit die betekenis van 'n vertroulike gesprek, dit wil sê, 'n gedagtewisseling tussen gelowiges onderling. Dit weer het aanleiding gegee tot 'n verdere ontwikkeling en word die betekenis van 'n godsdienslike rede daaraan gekoppel. Die homilie word dan prediking in die gemeente ${ }^{\tau}$. Die woord prediking wat deur ons gebruik word het sy oorsprong in die germanisering van die latynse praedicatio. Lg. het kērugma as Griekse sinoniem. Daar bestaan klaarblyklik nie altyd duidelikheid oor die begrip nie en die probleem ${ }^{8}$ is daarin geleē of dit aanduiding van die handeling is en of die inhoudelike ter sprake is. Vir ons is dit op die stadium nie van kardinale belang nie. Feit is dat God Hom in Woord en Daad openbaar. Friedrich ${ }^{9}$ sien dit in ieder geval so dat deur die prediking word die Logos openbaar. Hy betoog daarom dat kērugma ,ist die Art und Weise, in der der götliche Logos zu uns kommt."

Dit is ook goed om in aanmerking te neem dat daar 'n ander aspek is wat ook van belang is. Die werkwoord kērussein beteken eintlik proklameer. Hier hou dit die betekenis in van die

6. J. I. de Wet, Die Kerklike Verkondiging in die huidige Tydsgewrig, ongepubliseerde D.D.-proefskrif, Universiteit van Pretoria 1961, bl. 32

7. Vergelyk hiervoor bv. E. Chr. Achelis, Praktische Theologie, bewerk deur L. W. Bakhuizen van den Brink, Kemink en Zoon, Utrecht 1906 , bl. 173; Dr. H. Jonker, a.w., bl. 19, J. I. de Wet, a.w., bl. 25.

8. Kurt Goldammer, Der Kerugma-begriff in der ältesten christlichen Literatur, Z.N.W. 1957, bl. 79-83, gee hieraan aandag. Vergelyk ook G. Friedrich, Th.W.N.T. Bd. III bl. 715-716.

9. G. Friedrich, a.w., bl. 715,716 . 
gaeie boodskap, naamlik die heil wat God aankondig vir sy gelowiges.

\section{Die Openbaring van God}

Die opmerking in die voorgaande van Barth en ook dié van Friedrich bring ons by hierdie belangrike aspek van die openbaring van God.

Dit is so dat prediking net nie moontlik is sonder dat God Hom openbaar nie. Openbaring soos die Skrif dit bedoel hou in dat wat aan die mens onbekend is en hy deur sy eie vermoëns nie kan ken nie, aan hom bekend, dit is openbaar, gemaak word. Dit is derhalwe die bekendmaking van die Verborgene. Uitsluitlik word hier bedoel die bekendmaking van God self aan die mens. Die in sonde gevalle mens ontvang dus die openbaring van God as sy eiewillige heilshandeling aan die mens. God openbaar Hom in Jesus Christus en die Heilige Gees as die werksame in die mens is die Herskeppende en oortuig tot geloof.

Die kerk het die Bybel aanvaar as die outentieke getuienis van die openbaring van God in Jesus Christus ${ }^{10}$. Wanneer die kerk dus die verkondigingsopdrag ten uitvoer wil bring is die kerk gebonde aan hierdie enigste openbaringsgetuienis. Ek wil hier verwys na die eerste gedeelte van Art. VII van die Nederlandse Geloofsbelydenis. „Ons glo dat hierdie Heilige Skrif die wil van God volkomelik bevat en dat alles wat die mens moet glo om gered te word, daarin genoegsaam geleer word. Want aangesien die wyse waarop ons God volgens sy eis maet dien, daarin geheel-en-al en uitvoerig beskrywe is, is dit aan geen mens, al was dit ook die apostels, geoorloof om iets anders te leer nie as wat ons alreeds geleer word deur die Heilige Skrifte; ja, al was dit ook 'n engel uit die hemel, soos die apostel Paulus sê."

\section{Roeping en Opdrag}

Die voorgaande aanhaling word duidelik wanneer ons aandag gee aan die roepingsgeskiedenis van die profete. Hulle het ook in der waarheid net een taak en dit is om Gods Woord tuis te bring by die volk. Hulle moet as verkondigers optree en die een vereiste wat gestel word aan die ware profeet is dat hy nie sy eie woord durf spreek nie, en as hy dit sou waag om 'n woord te spreek wat hy nie ontvang het nie, moet hy volgens 'n uitspraak van Deut. 18: 20 sterwe. Ons vind talle uitdrukkings

10. Vgl. bv. Die Nederlandse Geloofsbelydenis, Art. 2-7. 
as aanduiding daarvan dat die woord van Jahwe ontvang is. Om 'n paar te noem : Die woord van die Here het tot die profeet gekom (I Sam. 15:10); Hiermee lê Ek my woorde in jou mond (Jer. 1:9). Die Woord wat God in my mond lê, dit sal ek spreek (Num. 22:38). By ander geleenthede word berig dat die Gees van Jahwe oor hulle gekom het (I Sam. 10:10).

Die logiese implikasie van hierdie gevalle is duidelik: God het hulle toegerus vir die taak wat $\mathrm{Hy}$ op hulle gelê het. Hulle moet derhalwe sy woord spreek en dit is bykans terminus tegnikus van hulle spreke om te verneem ko āmār JHWH ${ }^{11}$.

Die profete het die taak gehad om die woord wat hulle ontvang het tuis te bring by die volk en vir die volk is dit dieselfde om te luister na die stem van die profeet as om te luister na die stem van Jahwe ${ }^{12}$.

Die profete se belangrikste werk was om te preek. Hulle prediking moes die wil van Jahwe bekend maak (Jer. $31: 1$ v.v. $37: 3$ v.v., Eseg. $33: 30$ v.v.). Die prediking van die Ou Testamentiese profete het een en almal dieselfde inhoud gehad. Die toepassing het wel verskil na gelang van omstandighede ${ }^{13}$.

Gegewens in die Nuwe Testament wys op dieselfde aspekte as dié in die Ou Testament. Ons kan slegs let op die enkele gegewens in die Pauliniese briewe. Ons tref bv. die vermaning aan dat Timotheus die woord wat ontvang is suiwer moet oordra. In I Tim. 6:3, 4 word 'n persoon wat iets anders leer 'n verwaande genoem. Timotheus moet die woord van die waarheid reg sny (II Tim. 2:15). Hy is 'n navolger van Paulus in die leer (I Tim. $3: 10$ ) en hy moet bly in wat hy geleer het (II Tim. $3: 14$ ).

Die woord is nie staties nie. Timotheus kry opdrag om die woord te verkondig, en die woord moet ook toevertrou word aan bekwame manne (II Tim. $2: 2$ ). Paulus self maak nie aanspraak op 'n evangelie waarvan hy alleen-outeur is nie. Hy weet dat hy die evangelie "ontvang" het (I Kor. $15: 3$ en $11: 23$ ). Wat hy oordra het hy ontvang. Samevatting en fundamentele waarheid van die evangelie wat deur Paulus verkondig word vind ons in I Kor. 1:23: „Maar ons verkondig Christus wat gekruisig is." In I Kor. 15:1 siteer hy wat hy in Korinthe gepreek het, nl. die sterwe en opstanding van Jesus Christus uit die dood. Kērugma is vir Paulus derhalwe proklamasie van hierdie heils-

11. Eks. 4:22, 1 Sam. 10:18; 15:2; ens.

12. J. Lindblom, Prophecy in Ancient Israel, Basil Blackwell, Oxford, 1965, bl. 110, Jer. 1:9; Hag. 1:12.

13. J. Lindblom, a.w., bl. 311 . 
feite wat hy in eskatologiese verband sien ${ }^{11}$. Die vraag kan ook gestel word in hoeverre is die Pauliniese prediking en die van die apostels dieselfde? Paulus glo dat „sy" Evangelie op essensiële punte dieselfde is as dié van ander apostels. Volgens Gal. $2: 2$ is aan "sy" evangelie sanksie verleen deur Petrus, Jakobus en Johannes.

By die uitsending van die twaalf en eventueel ook van die sewentig kry hulle opdrag om te verkondig: die koninkryk van die hemele het naby gekom. Johannes die Doper se prediking word op hierdie wyse saamgevat. So geld dit ook vir die prediking van Jesus. Opvallend dus dat die opdrag wat die dissipels ontvang weergegee word met een en dieselfde sin. Vergelyk bv. Mark $1: 14,15$. . . het Jesus in Galiléa gekom en die evangelie van die koninkryk van God verkondig en gesê : Die tyd is vervul en die koninkryk van God het naby gekom; bekeer julle en glo die evangelie. Wat die hele inhoud van die prediking was is nie hieruit af te lei nie maar dat dit in breë trekke dieselfde is, glo ek nie kan aan getwyfel word nie.

In Handelinge vind ons 'n paar preke opgeteken ${ }^{15}$. Nou is dit wel so dat dit komposisies van die outeur kan wees maar vanweë sy noukeurige gebruik van sy bronne kan ons aanvaar dat die toesprake gebaseer is op wat in feite gesê is. Ons vind dat dieselfde onderdele in die gevalle behandel word ${ }^{16}$. Meer nog, dit is ook opvallend dat die predikers elke keer aansluiting vind in die Ou Testament en dat die gebeure met en rondom die Messias „volgens die Skrifte” plaasgevind het. Tereg merk Hesse hieromtrent op: „Alttestamentliche Zitate finden sich in der Apostelgeschichte überaus häufig, und zwar in erster Linie in den Reden der Apostel und des Stephanus. Auch diese Zitate werden in Sinne des Schemas Weissagung-Erfüllung verwendet" ${ }^{17}$. Ek hoef ook nie hier veel meer aandag te gee aan die bekende tekste soos Markus 16:15: Gaan die hele wêreld in en verkondig die

14. C. H. Dodd, De Apastolische Prediking en haar Ontwikkelingsgang, G. F. Callenbach N.V., Nijkerk s.j., bl. 15 .

15. Bv. Handeling $2: 14-36 ; 38-39 ; 3: 12-26$ en $4: 8-12$.

16. (a) Die tydperk van vervulling het aangebreek en dit is waarvan die profete gespreek het.

(b) Dit is meegebring deur die lewe, werk, dood en opstanding van Jesus.

(c) Deur die opstanding is Jesus verheerlik.

(d) Die Heilige Gees in die gemeente is Laben van Christus se aanwesige mag en heerlikheid.

(e) Die verwagting van die spoedige wederkoms.

(f) Die kērugma sluit altyd met 'n oproep tot bekering en die aan. bieding van die vergewing en van die gawe van die Heilige Gees. Vgl. C. H. Dodd, a.w., bl.

17. Franz Hesse, Das Alle Testament als Bach der Kirch Gütersloher Verlagshaus Gerd Mohn, Gütersloh 1966, bl. 62. 
Evangelie aan die ganse mensdom, nie. Alleenlik kan daarop gewys word dat hierdie verkondigingstaak dié van die kerk is. Die instelling van die verskillende ampte apostels, profete, evangeliste, herders en leraars, ouderlinge, opsieners ens. het daarom ook die doel dat hierdie taak en die uitvoering daarvan gekontinueer kan word tot aan die uiterste van die aarde.

Die verkondiging en met name die prediking is die opdrag aan diegene wat daarvoor uitverkies is. Hier kan ter stawing verwys word na Paulus se woord in Romeine 10:15: „En hoe kan hulle preek as hulle nie gestuur word nie?" Paulus self weet dat hy ' $n$ klètos apostolos is. Hy is geroepe en daarom verdedig hy telkens sy apostelskap heftig in die verskillende briewe.

\section{Die Woord van God}

Hierdie uitdrukking is nou al telkens gebruik. Dit is derhalwe noodsaaklik om net kortliks te verklaar wat daaronder verstaan word.

Dit kan die beste gedoen word in aansluiting by $\mathrm{Stam}^{18}$ : Volgens hom het die Woord van God drieërlei gestalte :

1. As openbaring van God. Hierdie openbaring geskied primêr in Jesus Christus want Hy is die Vleesgeworde Woord van God;

2. As die Heilige Skrif, dit is die getuienis van die openbaring van God in Jesus Christus;

3. As die verkondiging van die openbaring waarvan die Heilige Skrif die getuienis bevat.

Hiermee hang saam die een probleem wat op talle wyses geformuleer is en wat in die algemeen genoem word die waagstuk van die prediking. Hiermee word bedoel dat by die prediker die verwagting lewe dat deur Hom Gods Woord verkondig word, dat die mens wat nie goddelik is nie Gods Woord kan spreek. Hoe word dit waar wat ons lees in Luk. $10: 16$. Wie na julle luister, luister na my? Die antwoord hierop is deur die werking van die Heilige Gees. Prins ${ }^{19}$ het gewag gemaak van die trilogie Gees, Skrif en Amp as nalatenskap van Christus. Vir ons is van belang dat die algenoegsaamheid van die Heilige Skrif geloën sou word as daar nie sprake is van die Heilige Gees nie. Die Heilige Gees is volstrek onmisbaar. Tereg sê Prins dan ook dat

18. Dr. J. J. Stam, Rondom de Preek, Uitgewersmaatschappij Amsterdam 1946 , bl. 18.

19. Dr. P. Prins. De Heilige Geest en het ampt, in De Heilige Geest, J. H. Kok N.V., Kampen 1949, bl. 331. 
sonder die verligting van die Heilige Gees en die bewarende en korrigerende leiding en beskutting van die amp kan die volheid van die Skrif nie tot sy reg kom nie. Uit die voorgaande kan ons derhalwe voorlopig tot die volgende gevolgtrekkings kom:

(a) Die prediker spreek nie uit sy eie uit nie. Hy is geroepene soos die Nederlandse Geloofsbelydenis ook voorskryf : So moet elkeen dan daarvoor oppas om nie deur onbehoorlike middele homself in te dring nie, maar hy moet die tyd afwag dat hy deur God geroep word, sodat hy getuienis kan hê van sy beroeping om daarvan gewis en seker te wees dat dit van die Here kom (Art. XXXI).

(b) Hy spreek vanweë die opdrag wat hy daartoe ontvang het. Die eerste taak wat dan ook genoem word as die van die bedienaar van die Woord in die betrokke bevestigingsformulier is juis die uitvoering van hierdie opdrag.

(c) Hierdie opdrag plaas hom onder die tug: Wat hom voorgesê is, moet hy na sê. Dit is derhalwe so dat die prediking nooit toespraak is nie maar alleen kērugma of boodskap wat hy moet oorbring ${ }^{20}$.

(d) Hy moet Gods Woord bring. Hy spreek dus nie oor sy eie ervaring en al dergelike nie maar hy spreek wat hy van God ontvang het om te spreek. Hy sal wel gebruik maak van sy eie woorde maar dan diensbaar aan die Woord van God.

\section{Riglyne vir die Prediking :}

\section{(a) Amptelike Opdrag}

In artikel $\mathrm{V}$ van die Kerkwet van die Nederduitsch Hervormde Kerk van Afrika word bepaal dat aan die dienaars van die Woord toevertrou is die voorgaan by die openbare eredienste. Die kerk sien derhalwe die prediking ook as amptelike gebeure in die kerk waarvoor die kerk verantwoordelikheid aanvaar. Die kerk stel ook sekere vereistes alvorens iemand toegelaat word as bedienaar van die Woord in die kerk. Dit behels o.a. die voorgeskrewe akademiese kwalifikasies waardeur die kerk hom vergewis van die kennis van die Heilige Skrif asook van die aanverwante Teologiese Wetenskappe by die dienaar van die Woord.

20. Prof. dr. A. J. Rasker, Homiletische Richttynen $I$ in Postille 1959-1960, Boekencentrum N.V., 's-Gravenhage s.j., bl. 8. 
Die verdere implikasie is dat dit vir die kerk gaan om iemand wat kerklik geroepe is, of soos die confessio helvetica dit stel legitime vocatus, vgl. die Nederlandse Geloofsbelydenis Art. XXXI. Dit sluit derhalwe die moontlikheid van lekepredikers uit. Dit beteken voorts dat die prediker nooit oor 'n vrye kateder beskik nie. Hy spreek met 'n gesag wat nie eie is aan sy persoon nie maar deur die kerk aan hom verleen is. Hy spreek derhalwe soos die kerk spreek. Die kerk spreek deur sy mond. Vanweë 'n misverstand oor hierdie aangeleentheid gebeur dit dat bedienaars van die Woord hulle ontuis kan voel in die kerk. Hulle wil nie aanvaar dat hulle amptelike en derhalwe kerklike opdrag en vergunning ontvang het nie.

\section{(b) Gebondenheid van die Prediker}

Vanweë die amptelike opdrag aan die prediker sal hy derhalwe ook aan die belydenis van die kerk gebonde wees. Hierdie gebondenheid beteken dat die prediker gevrywaar word van enige willekeur. Wanneer die belydenis van die kerk dan ook verstaan word as die interpretasie wat die kerk aan die Heilige Skrif gee hou dit in dat hy langs die weg gelei word tot die regte verstaan van die Heilige Skrif.

\section{(c) Skriftuurlike Prediking}

Die prediking moet uitleg van die Heilige Skrif wees. Rasker $^{21}$ skryf in sy artikel oor die prediking: „Hierom moet die prediking skriftuurlijk zijn, omdat de Schrift het authentiek, het geldig getuignis van Christus is." Die inhoud van die prediking is derhalwe afgegrens as die inhoud van die Skrif. Tereg wys Rasker daarop en waarsku dat die ware Skriftuurlikheid gemis kan word in die prediking al word die stof geput uit die Heilige Skrif.

Myns insiens ontstaan die probleem van die sg. Social Gospel dan ook hier wanneer die prediking gesien word as die antwoord van God op die menslike vrae en sy nood, sosiale omstandighede ens. instede daarvan dat die prediking die vraag van God aan die mens is waarop die mens moet antwoord. Die opmerking van Barth kan by gevolg as korrektuur dien op alle prediking, nl. "Ich habe nichts darüber, sondern davon zu sprechen; ich habe nicht etwas zu sagen, sondern nur etwas nach zu sagen."

Vanselfsprekend moet in aanmerking geneem word wat

21. Prof. dr. A. J. Rasker, a.w., bl. 13. 
gesê is van die profete. Hulle moet die Woord wat aan hulle opgedra is, verkondig. By die hou aan die Skrif van die prediking moet ons dat God Hom openbaar en nie ons nie ${ }^{22}$.

Dit bring ons by die eksegese. Wanneer ons werklike Skriftuurlike prediking wil hou is dit noodsaaklik dat eksegese van die tekswoord sal plaasvind. Ons moet verstaan wat daar geskrywe is, en dit kan alleen geskied deur te luister na wat in die geheel van die Skrif gesê is. Die geykte term is dus hier van toepassing dat die Skrif deur die Skrif verklaar moet word. Eksegese is egter meer as net dit. Dit sal beteken dat die filologiese waarde van elke begrip ontleed en les bes sal die teks in sy teksverband ontleed moet word. Dan ontstaan die vraag na wat die teks vir ons in die hede te sê het. Regte eksegese beteken altyd dat vanuit die Skrif gewerk word en 'n omgekeerde volgorde is nie moontlik nie. Die geleentheid bepaal nie die eksegese nie. Bepaalde omstandighede en heersende vrae bepaal dit nog minder. Wanneer ons dit wil doen maak ons ons skuldig aan inlegkunde. Wanneer ons dit weet en toepas word die fyne onderskeiding van Vogel vir ons duidelik. Vir hom is die prediking "Gottes Wort in Menschenmund"23. Dit beteken dat in die prediking word die mensewoord diensbaar aan die openbaring en word die Woord van God beluister. Die Heilige Skrif is ,in actu" dan Gods Woord omdat die Heilige Gees dit as die middel gebruik om tot geloof te wek en te versterk. Dit is dus die aksie van God waarin die mens instrument is. Wanneer die regte eksegese gedoen word, word geluister na die spreke van God en dit word tuisgebring by die mens. Dan is nie ons outeur van ons prediking nie maar „Gott allein ist und bleib Autor, Schöpfer und Herr"'24

Stam het tereg opgemerk dat die bedoeling van alle juiste eksegese van die Heilige Skrif is om aan die verkondiging, Skrif en openbaring reg te laat geskied. Die eksegese moet ook derhalwe die gesag van die Skrif as Gods Woord aanvaar en erken. Die belangrike volgens Stam, en dit moet ons toegee, is dat die eksegeet as aangesprokene, as gelowige, moet luister om volledig reg te kan laat geskied aan wat geskrywe staan.

Hy sê dan ook: „Waar de Heilige Geest als de eigenlike outeur beleden wordt, is exegese van uit het geloof geboden. Dit is de voorwaarde, die God Stelt"'ss

22. K. Barth, a.w., bl. 34 .

23. Aangehaal deur Ditrich Rösler, Das Problem der Homiletik, artikel in Theologia Practica 1 Jahrgang 1966 Heft 1, Furche Verlag H. Rennebach KG, Hamburg, bl. 15.

24. Dietrich Rössler, a.w., bl. 15.

25. Dr. J. J. Stam, a.w., 1946, bi. 33 
Skrifgebonde prediking beteken dat alle prediking christosentries sal wees. Selfs die prediking van die Ou Testament is verkondiging van Jesus Christus. Oberholzer het dit so gestel : ". . . daar is net een maatstaf wat steeds aangelê kan en moet word om die geldigheid van die uitleg van die Ou Testamentiese Godsgetuienis te toets, nl. of Christus gestel word in die speerpunt van die Ou Testamentiese Godsgetuienis. Elke uitleg wat by Hom verbygaan sal deur die kerk afgewys moet word." Alle prediking is Christusverkondiging. God het Hom in Jesus Christus met ons versoen en in Hom is die straf vir die gelowige opgehef. Barth formuleer dit so: „Es ist vom Gott selber aus alles in Ordnung gebracht . . Allein das Gesehehen von Gott aus mit in Christus, das Immanuel, Gott mit uns - dies ist der Mittelpunkt aller Predigt. ${ }^{2 \tau}$ Alle prediking handel derhalwe oor die sonde as deur God vergewe. Alle prediking geskied op hierdie wyse, ook boeteprediking kan nie anders geskied as in die lig van die feit van God se erbarming in Jesus Christus nie!

Hierdie beklemtoning van die Skrifbekondenheid beteken nie dat daar slegs in die verlede besig gebly word in die prediking nie. Dit moet aktueel wees. Jonker ${ }^{23}$ het opgemerk dat die aktuele prediking laat die krag van die Woord geld in die hede, is ,,in actu”, d.w.s. werkend, handelend, geldend en singewend. Die prediking kan nie vervaag in die stelling van 'n hoeveelheid algemeenhede nie. In die prediking moet die aktualiteit van die Skrifwoord openbaar word deur aan te toon dat wat God sê aan Abraham of die Samaritaanse vrou of aan die gemeente van Korinthe juis ook vir die hoorder van die hede van belang is ${ }^{29}$. In die aktuele prediking word nie by die gemeentelid verby gespreek nie maar word op die man af gepreek en die mens van hier en nou word gekonfronteer met die gepredikte Woord. „In de prediking gaat het er dus om, dat de hoorder zal weten : dit woord is tot my gericht, ik ben door dit woord bedoeld." ${ }_{30}$ Dit lê in die mag van die Heilige Gees maar die bedienaar van die Woord het hier ook verantwoordelikheid: Hy moet verstaanbaar preek.

In die regte prediking word die hoorder dus gekonfronteer met die Woord van God.

26. J. P. Oberholzer, Christus verkondiging en die Ou Testament, HTS 19de Jaargang, Afd. I en II, Oktober 1963, bl. 1. (N.H.W.-Pers, Krugersdorp).

27. K. Barth, a.w., bl. 36 .

28. H. Jonker, a.w., bl. 21.

29. H. Berkhof, Eredienst en Preek voor die leek, artikel in Wending (Jaargang 16 no 10 Desember 1961), bl. 637, vgl. ook D. J. Booysen, Die Verkondiging van die Woord aan die Buitekerklikes, Ongepubliseerde D.D.-proefskrif, Universiteit van Pretoria, Pretoria 1966. bl. 109 v.c.

30. Dr. J. J. Stam, a.w., bl. 83. 
Hierdie prediking moet so geskied dat die gemeente daardeur opgebou word. Die regte prediking maet uiteindelik ten gevolg hê dat elkeen voor Hom die knie sal buig en elke tong Sy naam sal bely! 